\title{
Source Locality Effects on Restoration Potential in Sphagnum palustre L. from 3 Ohio Sites
}

TONYMILLER', Department of Biological Sciences, Kent State University, Kent, OH, USA and RANDALLJ.MITCHELL, Department of Biology, The University of Akron, Akron, OH, USA.

ABSTRACT. Understanding whether propagules from different donor sources differ in their performance at a site may be important for restoration of many habitats. This study aimed at evaluating source effects in Sphagnum palustre $L$, a peatland moss species, for potential use in a restoration setting. Tamarack Bog, a remnant peatland in Bath Township, Ohio, is being restored. One goal is to increase Sphagnum coverage. This study focused on the dominant species of peat moss at the bog, S. palustre. To test for source effects, S. palustre and water samples were collected from 3 different locations (Mentor Marsh, Tamarack Bog, and Singer Lake) and used in 2 experiments. Plant performance was assessed by measuring growth in length and increase in mass. In the first experiment, a full factorial test was conducted: moss sampled from each location was grown directly in water collected from each location. In the second experiment-also a full factorial test-moss sampled from each location was separately grown on a uniform, commercially harvested, peat substrate and supplied with water collected from each location. In the design of both experiments, local adaptation would be indicated by better performance (both experiments measured length change and mass change, plus capitulum counts in the second experiment) for plants grown in their home water source than for plants grown in water from other sites. Ultimately, the study team did not observe evidence for local adaptation in these experiments. However, there were strong plant source effects in both experiments and some indication of differences in response to the water from different sources. Interpreting these results from a restoration standpoint, using donor plants from several source sites may improve the success of restoration.

\section{INTRODUCTION}

Native plant restorations often involve the introduction of propagules from other sites to initiate or augment local populations (Hufford and Mazer 2003). In any one particular site, propagules from one source may be best; at a different site, another source may be superior. This pattern may reflect local adaptation of plant populations, an important concept in conservation (Leimu and Fischer 2008). Local adaptation occurs when an organism has higher fitness in its home habitat than in others (Williams 1966; Kawecki and Ebert 2004). Local adaptation can be tested by growing individuals from different populations of the same species together at a site or in a common garden; finding that individuals perform better under the conditions of their home site provides evidence for local adaptation (Williams 1966; Kawecki and Ebert 2004; Leimu and Fischer 2008). However, the differences in fitness are not always associated with genetic differences, such as the case with tolerance of sulfur compounds in the Sphagnum of the Southern Pennines (Lee and Studholme 1992), so local adaptation can be difficult to detect in Sphagnum.

${ }^{1}$ Address correspondence to Tony Miller, Department of Biological Sciences, 256 Cunningham Hall, Kent State University, Kent, OH 44242. Email: jmill222@kent.edu
Local adaptation may be especially important in understanding the biology and restoration of peatlands. Peatland restoration relies on reestablishment of appropriate vegetation, including particularly Sphagnum moss. Sources of propagules for Sphagnum reestablishment are typically chosen because of similar plant species composition and environmental conditions to those of the proposed restoration site (Quinty and Rochefort 2003), and because the sites are geographically nearby (Gorham and Rochefort 2003). These decisions capitalize on the fact that Sphagnum can sometimes perform better when grown in $\mathrm{pH}$ conditions most similar to those of the collection site (Såstad et al. 1999). In many plant species, local populations may have as much as $50 \%$ higher fitness than foreign populations (Hereford 2009). Therefore, studying source effects may also be useful in the restoration of peatlands.

Sphagnum often occurs along chemical and physical gradients (Andrus 1986), and local adaptation is one proposed mechanism explaining differential success along the gradients. $\mathrm{pH}$ is one important gradient

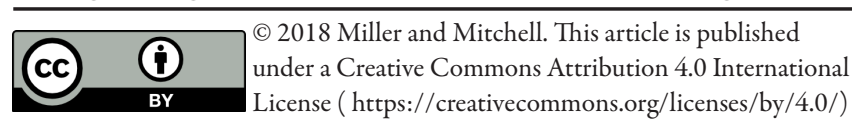


determining the species distribution of bryophytes in peatland habitats (Vitt and Chee 1990; Rydin and Jeglum 2013). Different haplotypes of $S$. fuscum (Schimp.) Klingrr. were found to occur in different microtopographic and $\mathrm{pH}$ conditions (Gunnarsson et al. 2007). Mikulášková et al. (2014) performed a principal coordinates analysis of $S$. warnstorfi genotypes and, of the 20 ecological variables measured, the only variable correlated with the genetic structure of the populations was $\mathrm{pH}$ (ranging from 4.3 to 7.2). However, numerous other ecological factors may affect responses. A study of $S$. magellanicum found that niche differentiation was driven by differences in light intensity, abundance of vascular plants, air humidity, and water table depth (Yousefi et al. 2017).

More research on local adaptation is needed to examine the causes and consequences of home and away differences (Kawecki and Ebert 2004). Here, we examine this topic for Sphagnum palustre L. This species occurs in a variety of $\mathrm{pH}$ conditions, ranging from acidic ( $\approx 3.9)$ to circumneutral (7.0; Andrus 1986; Hájková and Hájek 2007). Since $\mathrm{pH}$ gradients are important components of variation within peatlands (Rydin and Jeglum 2013), it would be beneficial to determine whether the different populations of $S$. palustre have differing localized water preferences.

This question was posed: Does water from different collecting sites affect $S$. palustre? To determine if source effects are important for $S$. palustre, plants from 3 source populations were grown in water collected from each location. If there are source effects, some S. palustre populations will perform well regardless of growth conditions. Evidence for source effects would encourage project managers to focus donor collections on sites with especially vigorous plants. Evidence against source effects would support collection of donor material for restorations from a broader range of environmental conditions.

\section{METHODS AND MATERIALS Site Characteristics}

Located in the Bath Nature Preserve in Bath Township, Ohio, a tamarack peatland (Tamarack Bog; lat $41^{\circ} 10^{\prime} 37^{\prime \prime} \mathrm{N}$, long $\left.81^{\circ} 38^{\prime} 35^{\prime \prime} \mathrm{W}\right)$ is shrinking because drainage ditches, established in the 1960s (Miletti etal. 2005), have greatly changed the hydrology and allowed invasive species to establish. Such peatland destruction is common and is a leading cause of wetland loss in Ohio (Andreas and Knoop 1992). Restoration efforts are now underway at the Tamarack
Bog to stabilize the remaining habitat, and help the degraded margins recover to their original state. One goal of the project is to improve Sphagnum coverage. Transplanting Sphagnum from donor sites may be necessary to achieve this goal. The study sought to better understand the potential of Sphagnum source to affect transplant success. This work involves $S$. palustre, the Sphagnum species that is most common in the Tamarack Bog (personal observation).

Three source populations were chosen for this study; all contained $S$. palustre, but were intended to provide differing environments for Sphagnum growth in terms of $\mathrm{pH}$ and light. The first location was the Tamarack Bog in Bath Township, Ohio. This site is categorized as a "poor fen," with substantial groundwater inflow and outflow and a circumneutral $\mathrm{pH}$ (6.5 to 7; Mezentseva 2015). The site is dominated by wetland shrubs such as Alnus incana, Vaccinium corymbosum, and Toxicodendron vernix that provide shaded conditions in the understory across the fen. Water levels are within $\approx 10 \mathrm{~cm}$ of the peat surface throughout the year (Miletti et al. 2005).

The second location was a red maple (Acer rubrum) swamp located in Mentor, Ohio (part of the Mentor Marsh complex; Bernstein 1981). At this location, S. palustre was growing on hummocks built up around the roots of dead and living $A$. rubrum. Also, at this site was an encroaching population of Phragmites australis, which, along with the red maples, provided mainly shaded conditions. The $\mathrm{pH}$ of the water at this site has not been previously reported in the literature. At Mentor Marsh, the swamp habitat had flooded conditions throughout the year.

The third location was an acidic kettle bog, Singer Lake Bog (hereafter referred to as Singer Lake), located near Green, Ohio. This location is an open, floating mat dominated by Sphagnum and leatherleaf (Chamaedaphne calyculata) with some poison sumac (Toxicodendron vernix) providing sparse shade. The S. palustre for the current study was collected from a hummock that receives sunlight throughout the day. The water level at Singer Lake appears to be steady throughout the year, so the collected Sphagnum was on a hummock between 10 to $20 \mathrm{~cm}$ above the water table.

For collections at each site, field identifications were confirmed using a microscope and identification key (Crum 1984) in the lab. All mosses from each site were collected from a single hummock, and the water was collected from the nearest pool (within 1 meter of the hummock). Rainfall in the month leading up to water 
collection was average or below average at each of the sites, so water conditions should be representative of typical conditions.

Two controlled experiments investigated whether the $S$. palustre from different sites responded differently to water sources. In experiment 1 , the moss from each source was grown directly in water from different sources. In experiment 2 , the moss was grown on a peat substrate and watered with water from those same sources.

\section{Experiment 1}

To test for local adaptation, $S$. palustre and source water were collected from each of the study's locations between June 24 and July 15, 2015. The water sources from Singer Lake and Tamarack Bog were collected on June 24 and 25, respectively. Samples from Mentor Marsh were collected on July 15 . An amount of 3.79 liters (1 US gallon) of water was collected from each location and then stored in the refrigerator (dark, $4{ }^{\circ} \mathrm{C}$ ). Twenty-four hours after collection, $\mathrm{pH}$ was measured with a temperature-compensated $\mathrm{pH}$ meter (VWR ${ }^{\circledR}$ SympHony ${ }^{\circledR}$ B10P). Nitrate, sulfate, and chloride concentration were also evaluated using ion chromatography (Dionex ${ }^{\mathrm{TM}}$ DX-100; Dionex Corp (now Thermo Scientific ${ }^{\mathrm{TM}}$ ); Sunnyvale, California). The Sphagnum - collected at the same time as the water-was stored in sealed clear-plastic bags in the refrigerator until the beginning of the experiment; storage times were between 1 to 3 weeks. The trials ran for 30 days beginning in late July 2015.

The first method of testing source effects was modeled after Ingerpuu and Vellak (2013). Beginning in July 2015, S. palustre from each location was grown in clear-plastic cups (radius $=5.5 \mathrm{~cm}$, height $=6.5$ $\mathrm{cm}$ ) for 30 days in a greenhouse (ranging between 22 to $24^{\circ} \mathrm{C}$ ). The experiment was designed as a full factorial of the 3 water source treatments and the 3 S. palustre source locations-with 9 replicates-for a total $\mathrm{n}=81$ cups. For each cup, 5 shoots of $S$. palustre from a particular location (with capitulum intact) were each cut to $1.5 \mathrm{~cm}$ length, and their combined fresh mass was measured following Ingerpuu and Vellak (2013; i.e., pressing shoots between paper towels for 3 seconds before weighing). The cups were initially watered with $15 \mathrm{~mL}$ of water from the appropriate source, and the fill line was marked on each cup. The cup was filled to the mark every Monday, Wednesday, and Friday. The cups were placed on trays in deep shade in The University of
Akron greenhouse, as earlier trials had shown that direct sunlight in these conditions led to desiccation. The design yielded 3 trays of cups that were rotated biweekly. Greenhouse temperatures were set at $22{ }^{\circ} \mathrm{C}$ with a natural photoperiod.

At the end of the experiment, the length of each shoot and the mass of the combined shoots were measured. When the experiment ended, some cups only contained 4 shoots. For this reason, and for each response variable, the mean value per shoot per cup was used in the analysis. Two of the collected water sources occasionally harbored duckweed (Lemna minor), which was removed. Also at the end of the experiment, some shoots had fragmented into unmeasurable pieces, resulting in final measurements using the mean of 4 shoots.

\section{Experiment 2}

A second experiment was conducted to assess the effect of each water source on each Sphagnum source. The design of the experiment entailed testing a full factorial of moss and water collected from the same 3 locations as in experiment 1, plus another water source (reverse osmosis water) as a control. As the mosses collected from the field were found growing at or above the water surface, a standardized substrate of commercially-harvested peat (Mosser Lee Co., Millston, Wisconsin) was used to provide a substrate for the mosses to grow on (different than experiment 1 , where the mosses were grown directly in water). Water and moss were collected in October 2015 using the same sources and methods as for experiment 1. A total of 37.9 liters (10 US gallons) of water was collected from each of the 3 locations and subsequently stored in refrigerated, opaque, tubs at the experiment location at The University of Akron greenhouse. Water $\mathrm{pH}$ and nutrient (nitrate, sulfate, and chloride) levels were measured after an initial 24-hour refrigeration period.

In preparation, the commercial peat was first soaked in reverse osmosis water for 3 days and then placed into 120 individual porous-plastic pots $(8 \mathrm{~cm}$ high $\times 6 \mathrm{~cm}$ long $\times 6 \mathrm{~cm}$ wide). S. palustre from each site was cut into uniform 0.5 -cm-long fragments (without capitula) and held in separate piles. Fragments were cut from the top $10 \mathrm{~cm}$ of the Sphagnum shoots, necessary because fragments from farther down on the shoot produce lower regeneration potentials in some species (Campeau and Rochefort 1996).

Eight fragments of $S$. palustre, all from the same source, were weighed (providing an initial fresh mass 
measurement) and placed into one of the previously prepared peat-filled pots. This was repeated for $\mathrm{n}=120$ pots: 40 containing exclusively Singer Lake moss, 40 containing exclusively Mentor Marsh moss, and 40 containing exclusively Tamarack Bog moss. Groups of 6 pots-2 each with moss from each of the 3 sources-were then placed together into 1 opentopped, clear plastic shoebox $(34.6 \times 21.0 \times 12.4$ $\mathrm{cm})$; resulting in a total of 20 identically configured shoeboxes. Next, 4 shoeboxes-each one labeled to receive water from 1 of the 4 different sourceswere then placed together into a 110-liter clear plastic container; resulting in a total of 5 identically configured clear plastic containers. Ultimately, the final configuration of experiment 2 (all 120 total pots) was enclosed within these 5 identically configured, 110-liter clear plastic containers: each container housing 2 replicates of the full factorial of water/ moss combinations. Later, during analysis, data on the 2 replicates in each of the 110-liter containers were averaged, yielding $n=5$ for each water/moss combination.

The experiment commenced in October 2015 and was planned for 90 days. During the experiment, the 6 pots in each shoebox were watered twice a week using 1 of the 4 different water treatments: the same source water being consistently applied to each shoebox at each watering. During watering each shoebox was filled to the level of the peat surface, allowing the common water source to flow into and saturate the peat in each pot.

Environmental conditions were monitored and controlled. Existing research (Bugnon et al. 1997; Price 1997; Price et al. 1998; Rochefort et al. 2003) and trials in the greenhouse indicate that maintenance of a moist microenvironment and high humidity is important in the establishment of Sphagnum. Therefore, the lids of the 110-liter containers were placed to maintain the humidity. To guard against any microhabitat variations in the greenhouse, the 110-liter containers were systematically rotated on a weekly basis. Additionally, any herbaceous plants emerging in the pots were carefully removed.

Experiment 2 was completed after 90 days. The growth of $S$. palustre in each of the 120 pots was determined by measuring final shoot length, mass change, and number of capitula. To obtain length measurements, a plastic ruler was placed into the peat and the longest shoot was measured from the peat surface to the head of the capitulum. The final fresh mass for each pot was measured, and the percent change in mass was then obtained by dividing the change in mass by the initial fresh mass.

\section{Analysis}

$\mathrm{JMP}^{\circledR}$ Pro 12 was used to run statistical tests on the above experiments. For water chemistry, an analysis of variance (ANOVA) was used to evaluate differences among sites and water collection dates. In each of the plant growth experiments, full factorial ANOVAs were used to observe effects caused by water location, Sphagnum location, and the interaction of these 2 categories. For post-hoc contrasts, we used the Tukey's test.

\section{Water Results}

\section{RESULTS}

Water chemistry varied greatly among sites and collection dates (Table 1). The $\mathrm{pH}$ differed among collecting sites $(\mathrm{p}<0.01)$, being highest in the Tamarack Bog and lowest in Singer Lake on both dates. Nitrate differed by collecting site and collecting date ( $p<0.0001$ for each). The nitrate was lowest in Singer Lake on both dates and, in July, highest in Mentor Marsh. However, in October, all 3 sites had similar and very low nitrate levels. Sulfate differed only by collection site $(\mathrm{p}<0.001)$ with Mentor Marsh having the highest sulfate levels. The chloride differed by collecting site and date $(p<0.01$ for each) with Mentor Marsh having higher chloride levels. Chloride levels were higher at each site in the October collection compared to the July collection.

Table 1

Water chemistry for the 3 source locations

\begin{tabular}{|c|c|c|c|c|c|c|c|c|}
\hline \multirow[t]{2}{*}{ Site } & \multicolumn{2}{|c|}{$\mathrm{pH}$} & \multicolumn{2}{|c|}{ Nitrate $(\mathrm{mg} / \mathrm{L})$} & \multicolumn{2}{|c|}{ Sulfate (mg/L) } & \multicolumn{2}{|c|}{ Chloride (mg/L) } \\
\hline & Jul $2015^{a}$ & Oct 2015 & Jul $2015^{a}$ & $\overline{\text { Oct } 2015^{b}}$ & Jul $2015^{a}$ & Oct 2015 b & Jul $2015^{a}$ & Oct $2015^{b}$ \\
\hline Tamarack Bog & 7.24 & 6.95 & 7.44 & 4.15 & 15.37 & 17.29 & 2.13 & 4.61 \\
\hline Mentor Marsh & 6.27 & 6.80 & 19.84 & 3.72 & 97.02 & 81.65 & 78.00 & 120.53 \\
\hline Singer Lake & 5.70 & 5.85 & 0 & 0.62 & 6.72 & 2.88 & 3.55 & 14.19 \\
\hline
\end{tabular}

${ }^{a} \mathrm{n}=1$; experiment $1 . \quad{ }^{\mathrm{b}}$ mean of $\mathrm{n}=2$; experiment 2 . 
Table 2

ANOVA values for experiment $1\left(\right.$ error $\left.D^{a}{ }^{a}=72\right)$

\begin{tabular}{|c|c|c|c|c|c|}
\hline Source & $\begin{array}{l}\text { Number of } \\
D^{a}\end{array}$ & $\begin{array}{l}\text { F ratio } \\
\text { (length) }\end{array}$ & $\begin{array}{l}\text { p-value } \\
\text { (length) }^{\mathrm{b}}\end{array}$ & $\begin{array}{l}\text { F ratio } \\
\text { (mass change) }\end{array}$ & $\begin{array}{l}\mathrm{p} \text {-value } \\
\text { (mass change) }^{\mathrm{b}}\end{array}$ \\
\hline Sphagnum source & 2 & 10.6853 & $<0.0001$ & 10.5358 & $<0.0001$ \\
\hline Water source & 2 & 43.2483 & $<0.0001$ & 15.8299 & $<0.0001$ \\
\hline Sphagnum $\times$ water source & 4 & 4.4797 & 0.003 & 1.2475 & 0.3 \\
\hline
\end{tabular}

${ }^{a}$ Degrees of freedom. $\quad{ }^{b}$ Bold type in column indicates values of $\mathrm{p}<0.05$.

\section{Experiment 1}

Length change in experiment 1 differed nearly 10 fold across all moss/water combinations (Fig. 1A), over 2-fold among Sphagnum sources, and nearly 3 -fold among water sources $(\mathrm{p}<0.0001$; Table 2$)$. The interaction of water and Sphagnum source was also significant $(\mathrm{p}=0.003)$. Every combination of Sphagnum source and water source gained some amount of length, but shoots from all sources performed best in Singer Lake water (Fig. 1A). Moss from the Tamarack Bog performed notably worse than the others in both Singer Lake and Tamarack Bog waters-but all 3 mosses performed similarly in Mentor Marsh water. Responses to water source were similar for moss from Singer Lake and Mentor Marsh, tending to be highest in Singer Lake water, and similarly low in the other sources. While the increase in length of the Tamarack Bog moss was not significantly different in the Singer Lake and Mentor Marsh water sources, the Tamarack Bog moss actually performed the worst (of any moss/ water combination) in water from its home source (Tamarack Bog).

Percent change in mass varied significantly with Sphagnum source and water source. Moss only gained mass in water from Singer Lake, and shoots from the Tamarack Bog lost mass in all water sources (Fig. 1B). For the water source effect, Tukey's test confirms that the advantage to growing in water from Singer Lake is significant, and that growth in water from Mentor Marsh and Tamarack Bog was not distinguishable. For the moss source effect, shoots originating from the Tamarack Bog lost significantly more mass than those collected from Mentor Marsh and Singer Lake (Tukey's comparison). Mentor Marsh and Singer Lake mosses were indistinguishable in terms of percentage gain (or loss) in mass.

\section{Experiment 2}

In experiment 2, the only significant cause of variation for any response variable was Sphagnum source, with water source and interaction not significant in all cases (Table 3). Percent gain in mass-averaged across all water sources-was nearly 20\% higher for Tamarack Bog moss than Singer Lake moss (Figure 2B; Table 3). The number of capitula produced was higher in Sphagnum originating from Mentor Marsh and Tamarack Bog than in the Sphagnum originating from Singer Lake (Fig. 2C); Mentor Marsh moss and Tamarack Bog moss having, on average, $\approx 1.5$ more capitula than Singer Lake moss (Table 3; Sphagnum source; $p=0.0002$ ). Final length was not significantly affected by either Sphagnum source or water source (Figure 2A; Table 3), although in 3 of 4 growth conditions, the Tamarack Bog moss grew longest.

Table 3

ANOVA values for experiment $2\left(\operatorname{error}^{\mathrm{DF}}{ }^{\mathrm{a}}=48\right)$

\begin{tabular}{llllllll}
\hline \hline Source & $\begin{array}{l}\text { Number } \\
\text { of DF }^{\text {a }}\end{array}$ & $\begin{array}{l}\text { F ratio } \\
\text { (length) }\end{array}$ & $\begin{array}{l}\text { p-value } \\
\text { (length) }\end{array}$ & $\begin{array}{l}\text { F ratio } \\
\text { (mass } \\
\text { change) }\end{array}$ & $\begin{array}{l}\text { p-value } \\
\text { (mass } \\
\text { change) }^{\mathbf{b}}\end{array}$ & $\begin{array}{l}\text { F ratio } \\
\text { (capitula } \\
\text { number) }\end{array}$ & $\begin{array}{l}\text { p-value } \\
\text { (capitula } \\
\text { number) }\end{array}$ \\
\hline Sphagnum & 2 & 1.2323 & 0.30 & 3.4603 & $\mathbf{0 . 0 4}$ & 10.4616 & $\mathbf{0 . 0 0 0 2}$ \\
Water & 3 & 0.2308 & 0.87 & 0.8766 & 0.46 & 1.5773 & 0.21 \\
Sphagnum $\times$ water & 6 & 0.3778 & 0.89 & 0.1028 & 0.99 & 0.7287 & 0.63 \\
\hline
\end{tabular}

${ }^{a}$ Degrees of freedom. $\quad{ }^{b}$ Bold type in column indicates values of $\mathrm{p}<0.05$. 
A

0.8

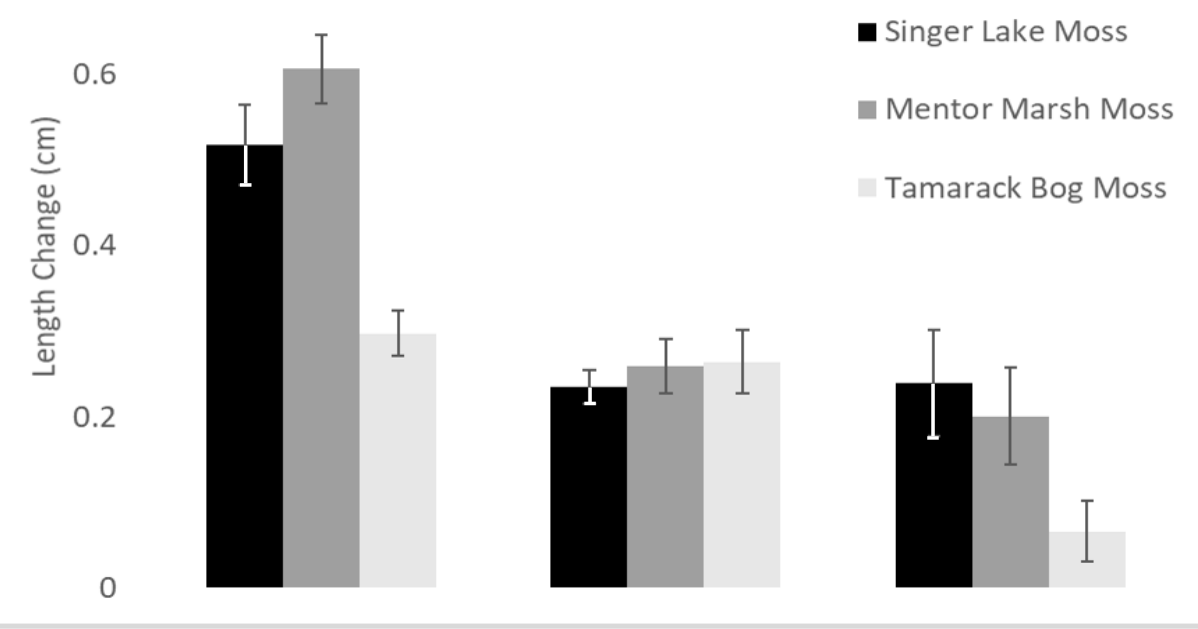

B

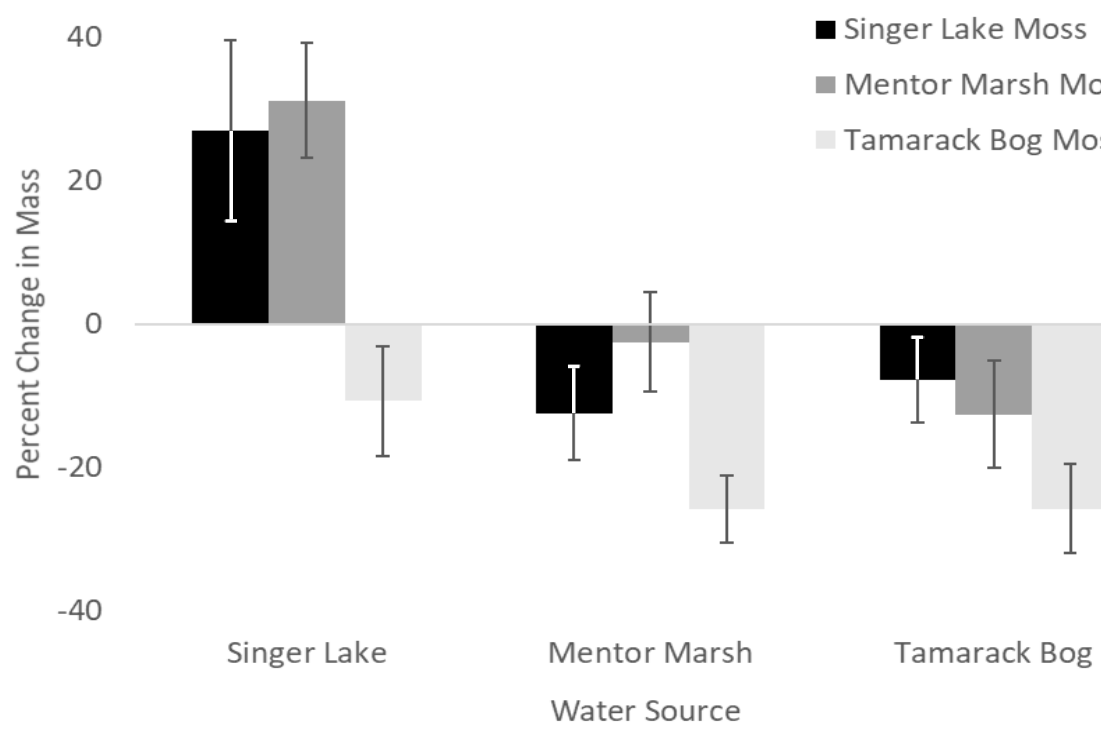

FIGURE 1. S. palustre (A) length change and (B) percent change in mass in experiment 1 (error bars represent $\mathrm{SE}$; $\mathrm{n} / \mathrm{bar}=9 \mathrm{cups}$ )

\section{DISCUSSION}

\section{Water Chemistry and Experiment 1}

Singer Lake water was more conducive to $S$. palustre growth than the Tamarack Bog or Mentor Marsh water sources. The Singer Lake water source was the only source that produced an increase in length and an increase in mass of Sphagnum in experiment 1. The other 2 water sources resulted in decreased mass. Referring to Table 1, there are a few possibilities that could explain this difference. One possible explanation for the better performance in the Singer Lake water source involves $\mathrm{pH}$. Clymo (1973) found that some Sphgnum species ( $S$. palustre was not tested) cannot withstand experimental increases in $\mathrm{pH}$. The Singer Lake water source was the lowest $\mathrm{pH}$ of the 3 wetlands
(5.70). However, S. palustre is commonly found in areas ranging in $\mathrm{pH}$ from 4.0 to 7.0 (Rydin and Jeglum 2013; although see also Andrus (1986) which suggests $\mathrm{pH}$ $>6.5$ is marginal for $S$. palustre). With the $\mathrm{pH}$ of the Tamarack Bog water $(\mathrm{pH}=7.24)$ being only slightly above this range-and with a similar change in mass in the Mentor Marsh $(\mathrm{pH}=6.27)$ and Tamarack Bog waters- $\mathrm{pH}$ is less likely to be a potential driver of the observed differences.

Another possible explanation is the concentrations of the different nutrients. Increases in nitrate, sulfur compounds, and chlorides have all been shown to reduce Sphagnum growth (Ferguson et al. 1978; Press et al. 1986; Wilcox 1986). Singer Lake water had less nitrate and sulfate than the other 2 sites. As for 

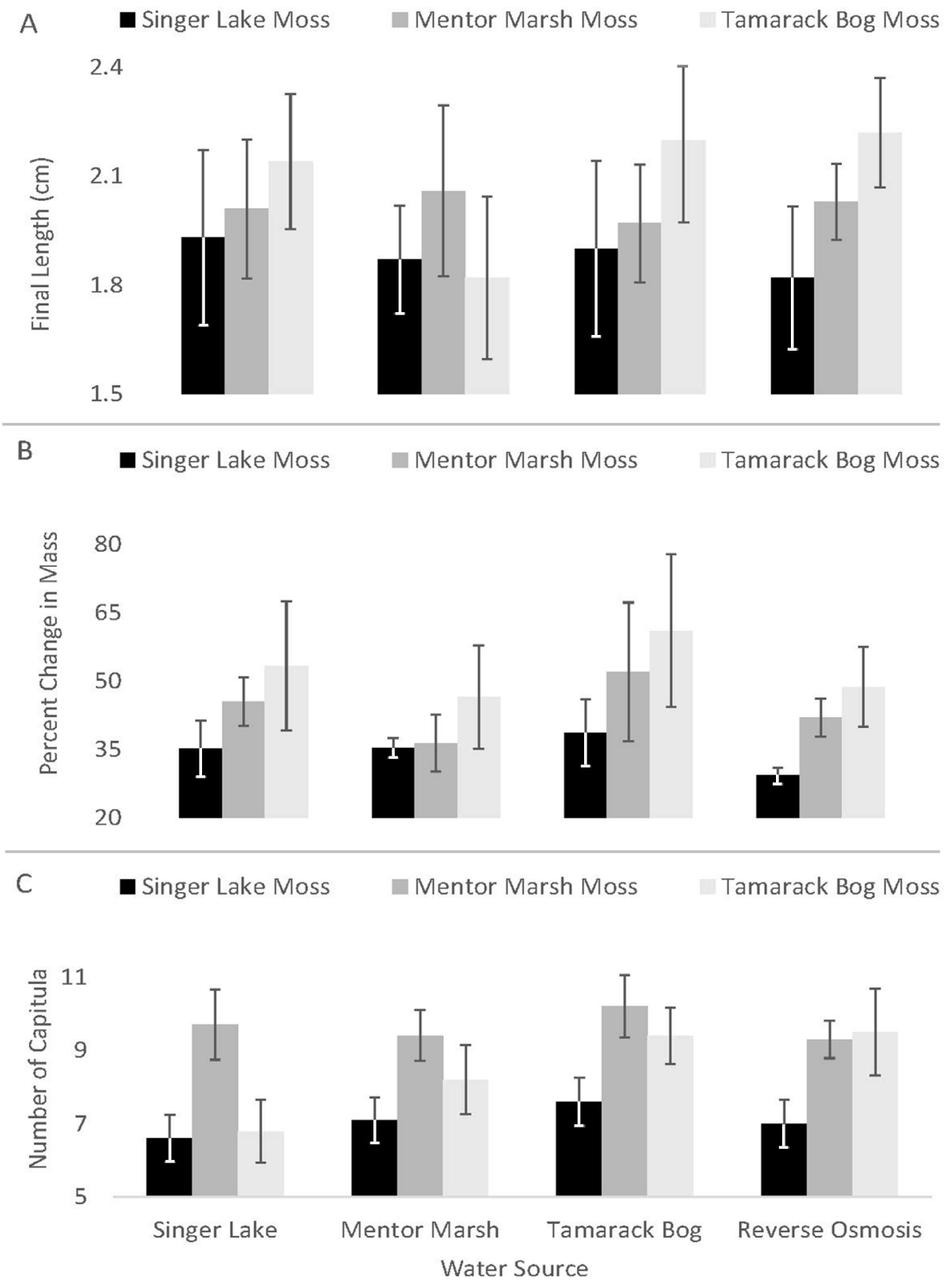

FIGURE 2. S. palustre (A) final length, (B) percent change in mass, and (C) number of capitula produced in experiment 2 (error bars represent $\mathrm{SE} ; \mathrm{n} / \mathrm{bar}=5$ replicates)

chloride, it was highest in the Mentor Marsh water (July $=78.00 \mathrm{mg} / \mathrm{L}$ ). This coincides with the history of Mentor Marsh. This site is fed by one stream that has experienced increases in chloride content because of nearby mining (Bernstein 1981). Yet another possible explanation is calcium. Increases in calcium can negatively impact Sphagnum growth (Clymo 1973). In November 2015, water samples were taken for measurements of calcium. The calcium level was lowest at Singer Lake $(4.01 \mathrm{mg} / \mathrm{L})$ and highest at Mentor Marsh (64.13 mg/L); Tamarack Bog water (32.06 mg/L) was intermediate between Singer Lake and Mentor Marsh. Calcium was in a different range than found in a study from the Netherlands, which found S. palustre in sites ranging from 20.04 to 90.18 $\mathrm{mg} / \mathrm{L}$ (Wassen et al. 1988). The data presented here cannot distinguish among these potential causes, but it is a useful focus for future research.

When comparing change in mass-and across all water sources-the moss collected from Mentor Marsh and Singer Lake outperformed the moss collected from the Tamarack Bog in experiment 1. In fact, the Tamarack Bog moss of experiment 1 ended up losing, on average across all water sources, $20 \%$ of its mass. This is a troublesome finding that suggests a lack of vigor for the $S$. palustre population at the Tamarack Bog: Even when grown in the water from Singer Lake and Mentor Marsh, this moss still lost mass. Also, 
the shoots (from all sites) grown in the Tamarack Bog and Mentor Marsh water sources appeared more frail than the shoots grown in the Singer Lake water source. In 7 of the 81 cups (and occurring in moss from all sites and in water from the Tamarack Bog and Mentor Marsh) the fragile shoots broke apart into unrecognizable pieces, and this led to the loss of a shoot. Additionally, shoots in at least 10 of the 81 cups (and occurring in moss from all sites) turned a grey-black color when grown in the Tamarack Bog or Mentor Marsh water sources. These 2 factors (shoot loss and color change) may indicate stressful conditions. Consistent with this, the Tamarack Bog and Mentor Marsh water sources had the highest measured $\mathrm{pH}$ and calcium levels, respectively.

\section{Experiment 2}

In experiment 2, the source of $S$. palustre was the only significant influence on plant growth; a result in contrast to experiment 1 . The $S$. palustre from Mentor Marsh and Tamarack Bog grew more capitula, and produced a higher percent increase of mass, than $S$. palustre from Singer Lake. This is promising for successful restoration, as capitulum development has been useful for measuring the regeneration success of Sphagnum. (Campeau and Rochefort 1996).

Interestingly, water source had no significant effect on moss growth in the peat substrate (experiment 2). When moss was grown directly in the water of the Tamarack Bog in experiment 1 , the moss from all sites lost mass on average and some shoots from each source were killed. However, when grown on a substrate and watered with the Tamarack Bog source (experiment 2 ), the mosses grew at similar rates as with the other water sources. One reason for this could be the seasonal differences in growth for this species. The growing season for $S$. palustre goes from spring to July, with the moss dying back from August on (Sobotka 1974). Moss for experiment 1 was collected in June and July, when mosses may have been at the end of their growing season, so they may not have grown well in the cups. Experiment 2 started in October, when mosses may have been emerging from late-summer dormancy and were therefore able to grow with more vigor.

Another interesting contrast between the 2 experiments was the behavior of the moss collected from the Tamarack Bog. In experiment 1 , the $S$. palustre of the Tamarack Bog had-in 5 of 6 cases-the least growth (or greatest loss) in terms of mass gain and length gain. When grown on a peat substrate, in experiment 2, the $S$. palustre of the Tamarack Bog had the highest percent change in mass gain in every case. Furthermore, in contrast to the observations in experiment 1 , there was no observed shoot loss or color change across the water source treatments in experiment 2 . One explanation for the differing results between the 2 experiments could be the filtering ability of peat. One area where peat has been shown to be an effective filter is in wastewater settings (Farnham and Brown 1972; Lens et al. 1994).

\section{Implications for Restoration}

The results of the greenhouse experiments provide information for bogs and fens undergoing restoration. First, the $S$. palustre in this experiment showed no evidence of local adaptation. This suggests that it is reasonable to make collections from a wide array of donor sites, as opposed to a narrow choice among source sites with similar vegetation and water conditions. This could be tested with a field transplant study. Secondly, the $S$. palustre collected from Mentor Marsh and Tamarack Bog formed significantly more capitula than the moss collected from Singer Lake. This provides evidence for the potential of vegetative reproduction (Cronberg 1992) because new shoots arise when a capitulum forms from a branch coming off the main stem.

As for the moss at the Tamarack Bog restoration site, it lost mass in each water treatment in experiment 1. This could simply reflect limits of growing directly in water with no substrate, or a problem with growth dormancy at that time of year. It could also indicate that the moss is not as healthy; however, given the results of experiment 2 , this does not seem likely.

The findings of this study identify 2 key points for restoration. First, with respect to growth, moss collections from any site would work for restoring the Tamarack Bog; however, restoration could be better fostered by using mosses with higher capitulum production. Second, when spreading diaspores at the restoration site, they should be spread on a peat substrate that is less susceptible to flooding and standing water.

\section{ACKNOWLEDGEMENTS}

Supported in part by Crowland Ltd., the Ohio Biological Survey Small Grants Program, and the Department of Biology of The University of Akron. Thanks to the Cleveland Museum of Natural History and Bath Township Parks for permission to collect from the different sites, and to Jim Toppin and Diane Lucas for help in Sphagnum identification. Jean Marie Hartman (Rutgers University) also provided advice and commented on an earlier draft of the manuscript. 


\section{LITERATURE CITED}

Andreas BK, Knoop JD. 1992. 100 years of changes in Ohio peatlands. Ohio J Sci. 92(5):130-138. http://hdl.handle. net/1811/23525

Andrus RE. 1986. Some aspects of Sphagnum ecology. Can J Bot. 64(2):416-426. https://doi.org/10.1139/b86-057

Bernstein NP. 1981. Vegetational history of Mentor Marsh. Ohio J Sci. 81(3):105-108. http://hdl.handle.net/1811/22775

Bugnon JL, Rochefort L, Price JS. 1997. Field experiment of Sphagnum reintroduction on a dry abandoned peatland in eastern Canada. Wetlands. 17(4):513-517. https://doi. org/10.1007/BF03161517

Campeau S, Rochefort L. 1996. Sphagnum regeneration on bare peat surfaces: field and greenhouse experiments. J Appl Ecol. 33(3):599-608. https://doi.org/10.2307/2404988

Clymo RS. 1973. The growth of Sphagnum: some effects of environment. J Ecol. 61(3):849-869. https://doi. org/10.2307/2258654

Cronberg N. 1992. Reproductivebiology of Sphagnum.Lindbergia. 17(4/6):69-82. http://www.jstor.org/stable/20149811

Crum HA. 1984. Sphagnopsida, Sphagnaceae. Bronx (NY): New York Botanical Garden. 180 p.

Farnham RS, Brown JL. 1972. Advanced wastewater treatment using organic and inorganic materials. Part I: Use of peat and peat-sand filtration media. In: Proceedings of the 4th International Peat Congress. Otaniemi (Finland): International Peat Society. p. 271-286.

Ferguson P, Lee JA, Bell JNB. 1978. Effects of sulphur pollutants on the growth of Sphagnum species. Environ Pollut. 16(2):151162. https://doi.org/10.1016/0013-9327(78)90129-5

Gorham E, Rochefort L. 2003. Peatland restoration: a brief assessment with special reference to Sphagnum bogs. Wetl Ecol Manag. 11(1-2):109-119. https://doi. org/10.1023/A:1022065723511

Gunnarsson U, Shaw AJ, Lönn M. 2007. Local-scale genetic structure in the peatmoss Sphagnum fuscum. Mol Ecol. 16(2):305-312. https://doi.org/10.1111/j.1365294X.2006.03144.x

Hájková P, Hájek M. 2007. Sphagnum distribution patterns along environmental gradients in Bulgaria. J Bryol. 29(1):18-26. https://doi.org/10.1179/174328207X160577

Hereford J. 2009. A quantitative survey of local adaptation and fitness trade-offs. Am Nat. 173(5):579-588. https://doi. org/10.1086/597611

Hufford KM, Mazer SJ. 2003. Plant ecotypes: genetic differentiation in the age of ecological restoration. Trends Ecol Evol. 18(3):147-155. https://doi.org/10.1016/S01695347(03)00002-8

Ingerpuu N, Vellak K. 2013. Growth depends on neighbours: experiments with three Sphagnum L. species. J Bryol. 35(1):2732. https://doi.org/10.1179/1743282012Y.0000000034

Kawecki TJ, Ebert D. 2004. Conceptual issues in local adaptation. Ecol Lett. 7(12):1225-1241. https://doi.org/10.1111/j.14610248.2004.00684.x

Lee JA, Studholme CJ. 1992. Responses of Sphagnum species to polluted environments. In: Bates JW, Farmer AM, editors. Bryophytes and lichens in a changing environment. Oxford (England): Oxford University Press. p. 314-332.

Leimu R, Fischer M. 2008. A meta-analysis of local adaptation in plants. PloS One. 3(12):e4010. https://doi.org/10.1371/ journal.pone.0004010

Lens PN, Vochten PM, Speleers L, Verstraete WH. 1994. Direct treatment of domestic wastewater by percolation over peat, bark and woodchips. Water Res. 28(1):17-26. https://doi. org/10.1016/0043-1354(94)90115-5
Mezentseva K. 2015. Hydrology of the Tamarack Bog, Bath Nature Preserve, Bath Township, Ohio [MS thesis]. [Akron $(\mathrm{OH})$ ]: The University of Akron. http://rave.ohiolink.edu/ etdc/view?acc_num=akron 1438166845

Mikulášková E, Hájek M, Veleba A, Johnson MG, Hájek T, Shaw JA. 2014. Local adaptations in bryophytes revisited: the genetic structure of the calcium-tolerant peatmoss Sphagnum warnstorfii along geographic and $\mathrm{pH}$ gradients. Ecol Evol. 5(1):229-242. https://doi.org/10.1002/ece3.1351

Miletti TE, Carlyle CN, Picard CR, Mulac KM, Landaw A, Fraser LH. 2005. Hydrology, water chemistry, and vegetation characteristics of a Tamarack bog in Bath Township, Ohio: towards restoration and enhancement. Ohio J Sci. 105(2):2130. http://hdl.handle.net/1811/31895

Miller JA. 2016. Monitoring of Sphagnum at a restoration site and possibilities for restorative activities [MS thesis]. [Akron $(\mathrm{OH})]$ : The University of Akron. http://rave.ohiolink.edu/ etdc/view?acc_num=akron 1466790016

Press MC, Woodin SJ, Lee JA. 1986. The potential importance of an increased atmospheric nitrogen supply to the growth of ombrotrophic Sphagnum species. New Phytol. 103(1):4555. https://doi.org/10.1111/j.1469-8137.1986.tb00595.x

Price J. 1997. Soil moisture, water tension, and water table relationships in a managed cutover bog. J Hydrol. 202(14):21-32. https://doi.org/10.1016/S0022-1694(97)00037-1

Price J, Rochefort L, Quinty F. 1998. Energy and moisture considerations on cutover peatlands: surface microtopography, mulch cover and Sphagnum regeneration. Ecol Eng. 10(4):293312. https://doi.org/10.1016/S0925-8574(98)00046-9

Quinty F, Rochefort L. 2003. Peatland restoration guide. 2nd ed. Quebec (Canada): Canadian Sphagnum Peat Moss Association and New Brunswick Department of Natural Resources and Energy. 106 p.

Rochefort L, Quinty F, Campeau S, Johnson K, MaltererT. 2003. North American approach to the restoration of Sphagnum dominated peatlands. Wetl Ecol Manag. 11(1-2):3-20. https:// doi.org/10.1023/A:1022011027946

Rydin H, Jeglum JK. 2013. The biology of peatlands. 2nd ed. Oxford (England): Oxford University Press. $432 \mathrm{p}$.

Såstad SM, Pedersen B, Digre K. 1999. Habitat-specific genetic effects on growth rate and morphology across $\mathrm{pH}$ and waterlevel gradients within a population of the moss Sphagnum angustifolium (Sphagnaceae). Am J Bot. 86(12):1687-1698. https://doi.org/10.2307/2656667

Sobotka D. 1974. Investigations on the growth and dying-back dynamics of Sphagnum palustre L. populations. Acta Soc Bot Pol.43(2):187-193. https://doi.org/10.5586/asbp.1974.017

Vitt DH, Chee WL. 1990. The relationships of vegetation to surface water chemistry and peat chemistry in fens of Alberta, Canada. Vegetatio. 89(2):87-106. https://doi.org/10.1007/ BF00032163

Wassen MJ, Barendregt A, Bootsma MC, Schot PP. 1988. Groundwater chemistry and vegetation of gradients from rich fen to poor fen in the Naardermeer (the Netherlands). Vegetatio. 79(3):117-132. https://doi.org/10.1007/ BF00044904

Williams GC. 1966. Adaptation and Natural Selection: a critique of some current evolutionary thought. Princeton (NJ): Princeton University Press. 307 p.

Wilcox DA. 1986. The effects of deicing salts on vegetation in Pinhook Bog, Indiana. Can J Botany. 64(4):865-874. https:// doi.org/10.1139/b86-113

Yousefi N, Hassel K, Flatberg KI, Kemppainen P, Trucchi E, Shaw AJ, Kyrkjeeide MO, Szovenyi P, Stenoien HK. 2017. Divergent evolution and niche differentiation within the common peatmoss Sphagnum magellanicum. Am J Bot. 104(7):1060-1072. https://doi.org/10.3732/ajb.1700163 